\title{
GMR
}

\section{A fast and simple method for the polymerase chain reaction-based sexing of livestock embryos}

K.C.S. Tavares', I.S. Carneiro', D.B. Rios', C. Feltrin', A.K.C. Ribeiro', S. Gaudêncio-Neto', L.T. Martins', L.H. Aguiar'1, C.R. Lazzarotto', C.E.M. Calderón', F.E.M. Lopes ${ }^{1}$, L.P.R. Teixeira ${ }^{1}$, M. Bertolini ${ }^{1,2}$ and L.R. Bertolini ${ }^{1,3}$

${ }^{1}$ Laboratório de Biologia Molecular e do Desenvolvimento, Núcleo de Biologia Experimental, Universidade de Fortaleza, Fortaleza, CE, Brasil 'Laboratório de Embriologia e Biotecnologia Reprodutiva,

Escola de Medicina Veterinária, Universidade Federal do Rio Grande do Sul, Porto Alegre, RS, Brasil

${ }^{3}$ Laboratório de Biotecnologia e Engenharia Genética,

Pontifícia Universidade Católica do Rio Grande do Sul, Porto Alegre, RS, Brasil

Corresponding author: K.C.S. Tavares

E-mail: kaio@unifor.br

Genet. Mol. Res. 15 (1): gmr.15017476

Received August 19, 2015

Accepted October 30, 2015

Published March 24, 2016

DOI http://dx.doi.org/10.4238/gmr.15017476

ABSTRACT. Embryo sexing is a powerful tool for livestock producers because it allows them to manage their breeding stocks more effectively. However, the cost of supplies and reagents, and the need for trained professionals to biopsy embryos by micromanipulation restrict the worldwide use of the technology to a limited number of specialized groups. The aim of this study was to couple a fast and inexpensive DNA extraction protocol with a practical biopsy approach to create a simple, quick, effective, and dependable embryo sexing procedure. From a total of 1847 sheep and cattle whole embryos or embryo biopsies, the sexing efficiency was $100 \%$ for embryo biopsies, $98 \%$ for sheep embryos, and $90.2 \%$ for cattle embryos. We used a primer pair that was common to both 
species and only $10 \%$ of the total extracted DNA. The whole protocol takes only $2 \mathrm{~h}$ to perform, which suggests that the proposed procedure can be readily applied to field conditions. Moreover, in addition to embryo sexing, the procedure can be used for further analyses, such as genotyping and molecular diagnosis in preimplantation embryos.

Key words: Embryo sexing; HotShot; Alkaline lysis; Preimplantation embryo diagnosis; PCR

\section{INTRODUCTION}

The ability to pre-select embryos prior to transfer based on genetic diagnosis is highly attractive to livestock producers, especially if applied to sex determination for milk or beef production (Park et al., 2001). Currently, there are at least four approaches to sex determination in ruminant species, based on the onset of development: a) artificial insemination using flow cytometry sexsorted semen (De Vries et al., 2008); b) polymerase chain reaction (PCR)-based detection of gender-specific sequences in preimplantation embryos prior to embryo transfer (Kageyama et al., 2004; Tsai et al., 2011); c) ultrasound fetal scanning of pregnant females in early pregnancy (Hughes and Davies, 1989; Davis and Haibel, 1993); and d) fetal DNA detection in the blood/serum of pregnant females (Wang et al., 2010; Kadivar et al., 2013). Each approach has its technical and economic advantages but also its limitations, and the choice of a particular procedure may depend on many factors. Those factors include the species and breed, the type of operation, the commercial goals, the breeding scheme, the adoption of reproductive technologies, and the need for sex pre-selection prior to the establishment of pregnancy.

Developed in the 1980s for cattle and horses, fetal gender determination by ultrasonography is the most common and widespread method for sex determination in livestock species, and is performed with high accuracy after day 55 of gestation in cattle (Ginther, 1998). Recently, fetal DNA detection using the plasma/serum of pregnant females (Davoudi et al., 2012) has also facilitated efficient and relatively non-invasive sex determination at distinct stages of gestation. However, both ultrasound scanning and fetal DNA detection in the dam's blood have the disadvantage of late sex determination, i.e., the determination is attained only after pregnancies are established and ongoing. This means that the farmer only learns the sex of the progeny, which is of interest to dairy cattle producers, but relevant only in terms of management decisions; there is no opportunity for sex pre-selection.

Although sperm cell sex sorting by flow cytometry was developed in the 1980s (Garner et al., 1983; Johnson et al., 1987), it only reached the market as a viable technology for the livestock industry in the late 1990s and 2000s (Seidel et al., 1999; Peippo et al., 2009); commercially, it is now used more than any other gender pre-selection method, such as PCR (Shea, 1999; Lopes et al., 2001) or loop-mediated isothermal amplification (Zoheir and Allam, 2010). In terms of efficiency, sex-sorted semen is intensively applied to artificial insemination and in vitro fertilization (IVF) procedures in cattle, but is regarded as inefficient for use with follicle stimulating hormonestimulated donor females owing to a lower embryo yield compared with the use of unsorted semen (Zhang et al., 2003). In addition, sperm sorting has been associated with reduced fertility (Grant and Chamley, 2007), premature sperm capacitation (Lu and Seidel, 2004), and lower blastocyst rates (Blondin et al., 2009) compared with non-sexed semen. Moreover, the procedure for sperm cell sorting can alter the semen IVF performance of certain bulls (Blondin et al., 2009), reducing 
the options for genetic diversity in breeding programs. In turn, embryo sexing by the PCR-based detection of $\mathrm{X}$ - and/or Y-specific regions in retrieved blastomeres is an alternative means of overcoming some of the limitations of the sexed semen for in vivo- or in vitro-produced embryos, allowing the producer to choose which embryo should be transferred to synchronous recipients based on sex determination (Mara et al., 2004; Carneiro et al., 2011; Rattanasuk et al., 2011). The molecular method is efficient for field applications, resulting in pregnancy rates comparable to nonbiopsied embryos, even after cryopreservation (Tominaga, 2004; Tominaga and Hamada, 2004). However, it is frequently the case that the cost of DNA extraction kits, supplies, and reagents in certain regions of the world, or even the impossibility of performing replicates owing to the use of the entire extracted DNA for a single PCR analysis (Lopes et al., 2001; Lopatarova et al., 2010) may limit the wider use of the procedure.

In this study, a fast, reliable, and cost-friendly adaptation of the HotShot alkaline lysis genomic DNA extraction protocol (Truett et al., 2000) was first validated in 530 samples of goat cultured somatic cells to achieve optimum efficiency. The protocol was then used to determine the sex of 1847 bovine and ovine embryos and biopsies, employing a common amelogenin gene-directed primer pair for domestic ruminant species that can be readily and effectively applied to field conditions.

\section{MATERIAL AND METHODS}

\section{Experiments and chemicals}

This study was divided into three main experiments, aiming to validate the use of the alkaline lysis DNA extraction method first in cells in culture, then in whole bovine and ovine embryos, and finally in biopsied embryos. All chemicals and reagents were from the Sigma-Aldrich Chemical Co. (St. Louis, MO, USA) and Invitrogen (Carlsbad, CA, USA), unless stated otherwise. Primers were from Integrated DNA Technologies (USA), and the PCR Mastermix was from Quatro G P\&D Ltd. (Porto Alegre, RS, Brazil).

\section{Experiment 1: PCR amplification of large (550 bp) and small (150 bp) amplicons from goat fetal fibroblasts transgenic to the human lysozyme gene (hLZ)}

\section{Cell culture and biopsies}

Goat fetal fibroblast cells, transgenic to the $\mathrm{hLZ}$, were cultured in vitro in tissue culture medium 199 (M2520, Sigma-Aldrich Chemical Co.) at $38.5^{\circ} \mathrm{C}$ and in $5 \% \mathrm{CO}_{2}$. Low passage $\mathrm{hLZ}$ transgenic fibroblast cultures were split onto $10-\mathrm{cm}$ culture dishes with 400 cells per dish. After 11-14 days, the fibroblasts were biopsied using a yellow micropipette tip attached to a 200- $\mu \mathrm{L}$ micropipette. For each sample collection, the tip was dragged on the semi-confluent plate and the floating cells aspirated and dispersed into one of the wells of a 96-well plate. A total of 530 independent samples were collected, with an average of 20 to 100 cells per biopsy (see Figure 1).

\section{DNA extraction and PCR}

Biopsied goat $\mathrm{hLZ}$ cells were centrifuged at $4000 \mathrm{~g}$ for $10 \mathrm{~min}$, the medium was removed, and a $200 \mathrm{mM} \mathrm{NaOH}$ solution $(2 \mu \mathrm{L})$ was added to each well. Samples were heated at $68^{\circ} \mathrm{C}$ for 10 min and neutralized with $2 \mu \mathrm{L} 1 \mathrm{M}$ Tris- $\mathrm{HCl}$ solution at $\mathrm{pH} 7.75$. 

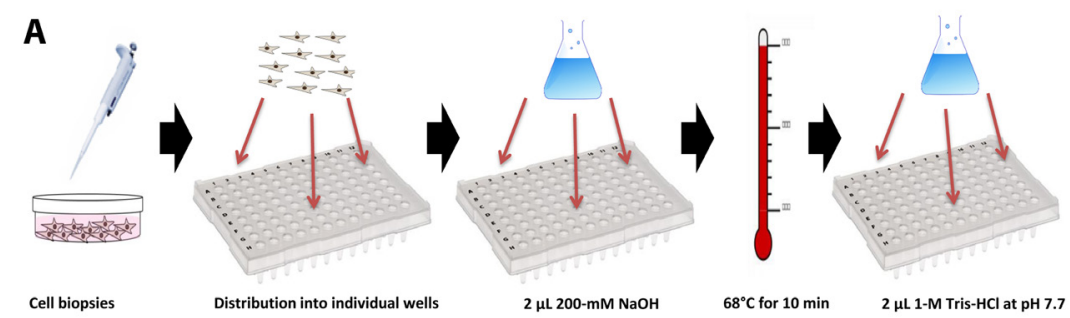

B

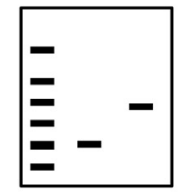

Electrophoresis

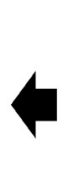

(

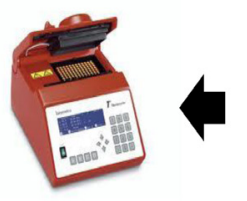

PCR

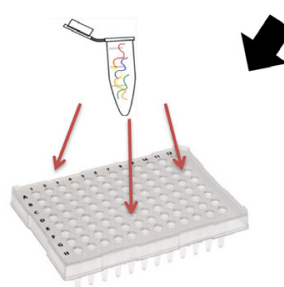

Addition of primers and PCR Mastermix

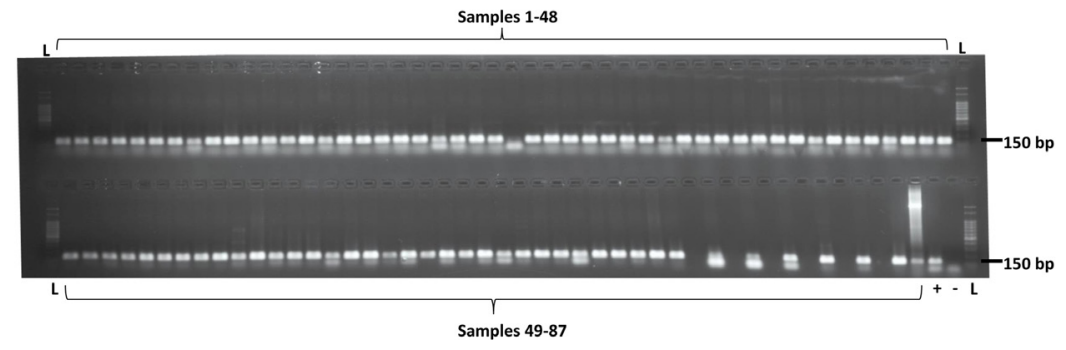

Figure 1. A. Cell biopsy procedure, DNA extraction, and polymerase chain reaction (PCR) scheme. After biopsy, all the steps were performed on the same 96-well PCR plate. B. Representative agarose gel of GAPDH amplification from 87 biopsies using the alkaline lysis DNA extraction protocol, where $L$ is the 100 bp ladder (Ludwig Biotech, Porto Alegre, RS, Brazil), + is the positive PCR control, and - is the negative PCR control.

Two distinct amplifications, based on the size of the amplicon, were performed: one for a 150-bp product for the GAPDH gene (GenBank XM_005680968.1) in a total of 263 samples; and the other for a 550-bp amplicon for the hLZ transgene (GenBank A10156.1) in 267 samples. PCR Mastermix ( $45 \mu \mathrm{L}$ ) (Quatro G P\&D Ltd.) was added directly to each well with the specific primer $(0.5 \mu \mathrm{M})\left(\right.$ Table 1). Samples were denatured at $95^{\circ} \mathrm{C}$ for 5 min followed by 40 cycles of $95^{\circ} \mathrm{C}$ for 30 $\mathrm{s}, 58^{\circ} \mathrm{C}$ for $30 \mathrm{~s}$, and $72^{\circ} \mathrm{C}$ for $30 \mathrm{~s}$, with a final extension at $72^{\circ} \mathrm{C}$ for $10 \mathrm{~min}$. Each sample $(10 \mu \mathrm{L})$ was analyzed on a $2 \%$ agarose gel to visualize the specific band patterns.

Table 1. Sequence, GenBank accession No., and amplicon sizes of the primers used in the study.

\begin{tabular}{l|l|l|c}
\hline Gene & Sequence 5'-3' & GenBank accession No. & Amplicon size (bp) \\
\hline \multirow{2}{*}{ Amelogenin } & F-CCCAAACCTCCCTCTGC & NC_022322.1 & $280 / 217$ \\
\cline { 2 - 2 } & R-CCGCTTGGTCTTGTCTGTTGC & & \\
\hline \multirow{2}{*}{ GAPDH } & F-GATTGTCAGCAATGCCTCCT & XM_005680968.1 & 150 \\
\cline { 2 - 2 } & R-AAGCAGGGATGATGTTCTGG & & 550 \\
\cline { 1 - 2 } Human lysozyme & F-CTTACATAGATCTTGGATCTCG & A10156.1 & \\
\cline { 2 - 2 } & R-CAATTTGAATGTATGGGATC & & \\
\hline
\end{tabular}




\section{Experiment 2: gender determination of bovine and sheep whole embryos using alkaline lysis and PCR}

\section{In vitro production (IVP) of cattle and sheep embryos}

A total of 1790 cattle and 41 sheep embryos were produced in vitro following established procedures (Ribeiro et al., 2009; Feltrin et al., 2014). Briefly, cattle and sheep ovaries were obtained post-mortem from a local slaughterhouse and transported in Dulbecco's phosphate-buffered saline to the laboratory in an insulated container at $33^{\circ} \mathrm{C}$. Cumulus-oocyte complexes (COCs) were obtained by follicular aspiration for cattle and by ovary slicing for sheep ovaries. Viable COCs, selected based on morphological quality, were in vitro-matured for $22 \pm 2 \mathrm{~h}$. For IVF, straws with frozen bovine or ovine semen were thawed and sperm cells were segregated by swim-up at $39^{\circ} \mathrm{C}$, $5 \% \mathrm{CO}_{2}$, and $95 \%$ relative humidity, in Sperm-TALP medium for up to $60 \mathrm{~min}$. After centrifugation at $500 \mathrm{~g}$ for $5 \mathrm{~min}$, the sperm cell concentration was adjusted to $1 \times 10^{7}$ spermatozoa/mL in TALPIVF medium. Groups of 10 to 15 COCs were arranged in microdroplets in TALP-IVF medium under mineral oil, and received a dose of $1 \times 10^{6}$ viable spermatozoa $/ \mathrm{mL}$. The spermatozoa were then co-incubated for $18-22 \mathrm{~h}$ at $39^{\circ} \mathrm{C}, 5 \% \mathrm{CO}_{2}$, and $95 \%$ relative humidity. Following IVF, embryos were in vitro-cultured (IVC) on 4-well dishes (Nunc, Denmark) containing $400 \mu \mathrm{L}$ modified synthetic oviductal fluid medium under mineral oil, and then incubated in $5 \% \mathrm{CO}_{2}, 5 \% \mathrm{O}_{2}$, and $90 \% \mathrm{~N}_{2}$ at $39^{\circ} \mathrm{C}$ and saturated humidity for 6-7 days to the blastocyst stage.

\section{DNA extraction and PCR}

Embryos at the blastocyst stage were subjected to enzymatic zona pellucida removal in $0.5 \%$ protease solution. These structures were washed twice in drops of phosphate-buffered saline, placed in a $0.2-\mathrm{mL}$ DNase-free tube containing $5 \mu \mathrm{L}$ ultra-pure water, and stored at $-20^{\circ} \mathrm{C}$ until required for analysis. Samples were thawed at room temperature and $400 \mathrm{mM} \mathrm{NaOH}$ solution $(5 \mu \mathrm{L})$ was added to each tube. After homogenization, samples were incubated at $68^{\circ} \mathrm{C}$ for $10 \mathrm{~min}$, then the reaction was neutralized by adding $1 \mathrm{M}$ Tris- $\mathrm{HCl}(10 \mu \mathrm{L}), \mathrm{pH} 7.75$. PCR was performed using primers targeting the Class I (X) and II (Y) amelogenin loci (Ennis and Gallagher, 1994), resulting in an amplicon of $280 \mathrm{bp}$ for the female genotype (only $\mathrm{X}$ ), and two amplicons of 280 bp and $217 \mathrm{bp}$ for the male genotype $(\mathrm{XY})$. Each reaction mixture comprised $0.5 \mu \mathrm{M}$ each primer (Table 1), $2 \mu \mathrm{L}$ DNA, and PCR Mastermix, according to the manufacturer instructions. Samples were denatured at $95^{\circ} \mathrm{C}$ for $5 \mathrm{~min}$ followed by 30 cycles of $95^{\circ} \mathrm{C}$ for $30 \mathrm{~s}, 65^{\circ} \mathrm{C}$ for $30 \mathrm{~s}$, and $72^{\circ} \mathrm{C}$ for $30 \mathrm{~s}$, with a final extension at $72^{\circ} \mathrm{C}$ for $10 \mathrm{~min}$. Blood DNA from a bull and a cow was extracted using the PureLink Genomic DNA Extraction Kit (Invitrogen) and used as positive controls. PCR products were subjected to electrophoresis on a $2 \%$ agarose gel for $40 \mathrm{~min}$ at $10 \mathrm{~V} / \mathrm{cm}^{2}$. Gels were stained using GelRed (Biotium, Hayward, CA, USA) and images were taken using the FluorChem FC2 Imaging System (Alpha Innotech, San Leandro, CA, USA).

\section{Experiment 3: molecular sexing of embryo biopsies}

\section{Embryo biopsies, DNA extraction, and PCR}

A total of 16 zona-free ovine embryos were manually sectioned at about $30 \%$ of their 
total volume in tissue culture medium 199 containing $2.5 \mu \mathrm{g} / \mathrm{mL}$ cytochalasin B. Embryo biopsies were immediately washed twice in phosphate-buffered saline and stored in $5 \mu \mathrm{L}$ ultra-pure water at $-20^{\circ} \mathrm{C}$. DNA extraction and PCR were carried out according to the method described above in the DNA extraction and PCR section (see Table 1). Biopsied embryos were in vitro-cultured for a further $24 \mathrm{~h}$ for the evaluation of survival and re-expansion and/or hatching rates.

\section{Data analyses}

Data regarding analysis efficiency (percentage of successful sex determinations per sample) between batches (bovine intact embryos), species (sheep vs cattle), sample type (whole embryo vs embryo biopsies), male:female ratio, and amplicon size influence on the PCR results using alkaline lysis DNA extraction were analyzed using the $\chi^{2}$ test for $P<0.05$.

\section{RESULTS}

\section{Experiment 1: amplicon size influence on the PCR efficiency for hLZ transgenic goat cells}

Figure $1 \mathrm{~A}$ shows the method used to obtain cell biopsies in culture, the DNA extraction by alkaline lysis, and the PCR procedures to detect the genes of interest. In Experiment 1, a total of $530 \mathrm{hLZ}$ transgenic goat fibroblast colony biopsies were analyzed in two groups: 263 samples were submitted to a PCR with a small amplicon size (SA), using primers for the GAPDH gene; and 267 were screened for a large amplicon size (LA), using primers for the $\mathrm{hLZ}$ transgene. As shown in Table 2, PCR efficiency in the SA group was significantly higher than in the LA group (99.6 vs $80.1 \%, P<0.05)$, suggesting that the proposed DNA extraction method is more effective when a small segment of DNA is amplified.

Table 2. Number of sexed samples, efficiency, and sex ratio using the alkaline lysis protocol.

\begin{tabular}{l|c|c|c|c|c|c|c}
\hline \multirow{2}{*}{ Groups } & Samples & \multicolumn{2}{|c|}{ Positive PCR } & \multicolumn{4}{|c}{ Sex ratio } \\
\cline { 2 - 8 } & $\mathrm{N}$ & $\mathrm{N}$ & $\%$ & Male & $\%$ & Female & $\%$ \\
\hline Cells-SA $^{1}$ & 263 & 262 & $99.6^{\mathrm{a}}$ & $\mathrm{NA}$ & $\mathrm{NA}$ & $\mathrm{NA}$ & NA \\
Cells-LA $^{2}$ & 267 & 214 & $80.1^{\mathrm{b}}$ & $\mathrm{NA}$ & $\mathrm{NA}$ & $\mathrm{NA}$ & NA \\
Bovine embryos & 1790 & 1615 & 90.3 & 932 & $57.7^{\mathrm{aA}}$ & 683 & $42.3^{\mathrm{aB}}$ \\
\hline Ovine embryos & 41 & 40 & $97.6^{\mathrm{a}, \mathrm{c}}$ & 18 & $45.0^{\mathrm{aA}}$ & 22 & $55.0^{\mathrm{aA}}$ \\
\hline Embryo biopsies & 16 & 16 & $100.0^{\mathrm{a}, \mathrm{c}}$ & 11 & $68.8^{\mathrm{aA}}$ & 5 & $31.2^{\mathrm{aB}}$ \\
\hline
\end{tabular}

$\mathrm{PCR}=$ polymerase chain reaction. ${ }^{1} \mathrm{SA}=$ samples that were screened for a small amplicon size $(150 \mathrm{bp})$ in the $\mathrm{PCR}$ for the GAPDH gene. ${ }^{2} \mathrm{LA}=$ samples that were screened for a large amplicon size (550 bp) in the PCR for the $\mathrm{hLZ}$ transgene. $\mathrm{NA}=$ not analyzed. ${ }^{\mathrm{a}, \mathrm{b}, \mathrm{c}}$ Numbers with distinct superscripts in the column differ for $\mathrm{P}<0.05 .{ }^{\mathrm{A}, \mathrm{B} N u m b e r s}$ with distinct superscripts in the row differ for $\mathrm{P}<0.05$.

\section{Experiments 2 and 3: alkaline lysis DNA extraction coupled with molecular sexing of embryos and embryo biopsies}

The alkaline lysis protocol was applied to bovine and ovine embryos, with the aim of developing a fast and cheap embryo sexing protocol. The developed protocol in Experiment 2 is summarized in Figure 2A. All steps were performed in the minimum required time; DNA extraction took less than $20 \mathrm{~min}$, and the sex determination of each batch of embryos was achieved in 110 min, making a total of 130 min for each group of embryo sexing analyses. 
A

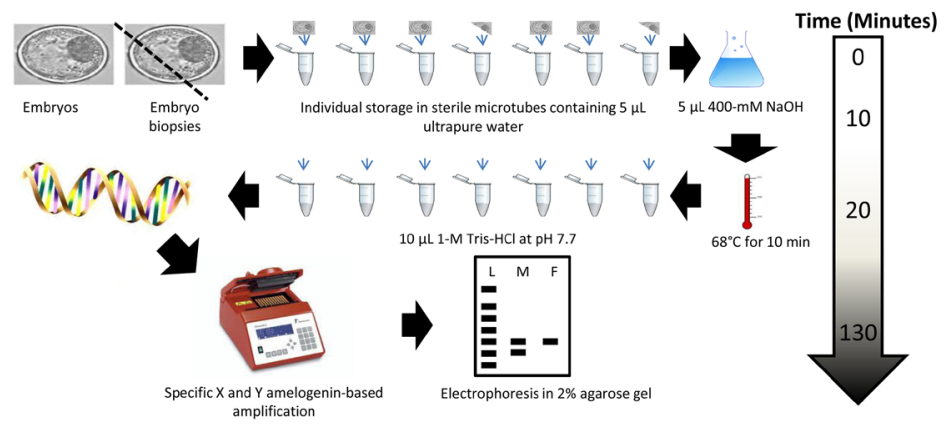

B

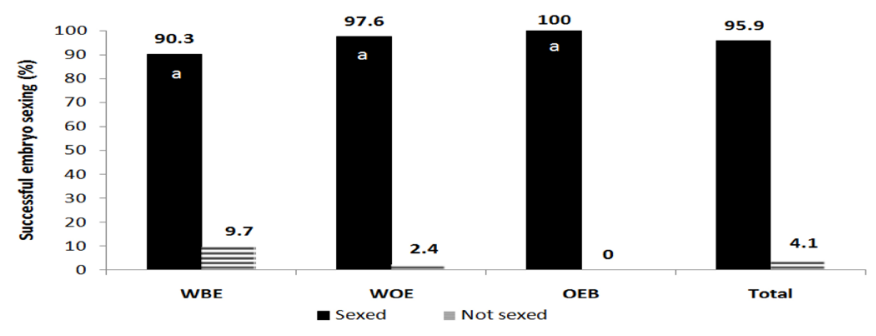

C

D

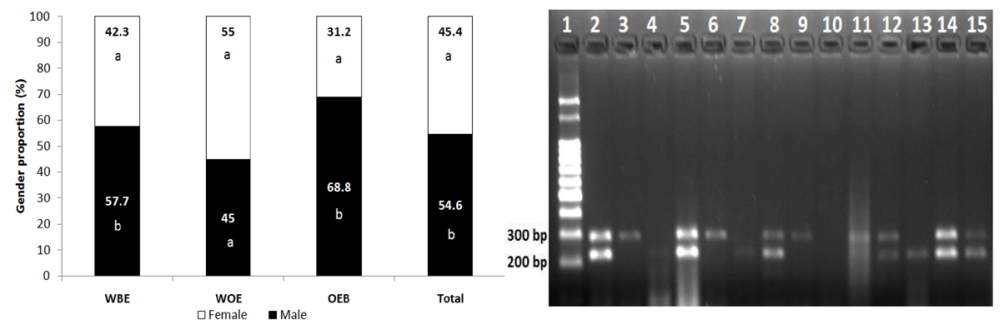

Figure 2. Embryo sexing workflow, efficiency, gender proportion, and electrophoresis results. The steps and the time course for carrying out the developed embryo sexing protocol are summarized in A. DNA extraction can be performed in $20 \mathrm{~min}$, and the polymerase chain reaction (PCR) and agarose gel electrophoresis in $110 \mathrm{~min}$ or less. The efficiency of embryo sexing for each group and the total mean efficiencies are shown in B., where WBE is whole bovine embryos, WOE is whole ovine embryos, and OEB is ovine embryo biopsies. "a" shows that there are no differences between numbers, for $\mathrm{P}<0.05$. The gender proportion of males and females for each group and the total male and female $\%$ are shown in C. D. Results of a $2 \%$ agarose gel electrophoresis, where lane 1 shows the 100 bp ladder (Ludwig Biotech), and lanes 2 to 15 represent embryo samples. In each lane, two bands (280 and $217 \mathrm{bp}$ ) represent a male specimen, and one band (280 bp) represents a female specimen. Note that the sex could not be determined in lane 10 owing to no amplification.

Table 2 summarizes the results for sex determination efficiency between the sample groups. For intact cattle embryos, a total of 1615 out of 1790 samples $(90.2 \%)$ resulted in successful sex determination (Table 2 and Figure 2B). For sheep embryos, 97.6\% (40/41) and 100\% (16/16) of the intact embryos and embryo biopsies were successfully sexed, respectively (Table 2 and Figure 2B); the results were statistically similar. There were no embryo losses after biopsy, i.e., all embryos re-expanded and/or hatched after $24 \mathrm{~h}$ of IVC. The mean efficiency for sheep embryos was $98.2 \%$, being similar to cells in the SA group and different $(P<0.05)$ from the bovine samples. Overall, sex determination by $\mathrm{NaOH}$-based PCR analysis for sheep and cattle embryos was $95.9 \%$ efficient (Figure 2B). 
No differences in sex ratio were observed between the groups (Table 2). However, within groups, the proportion of males was slightly higher than females for bovine embryos and embryo biopsies, while no differences were detected for intact sheep embryos (Table 2 and Figure 2C). The PCR outcome on the agarose gel for embryo sexing is illustrated in Figure 2D, in which lanes with two bands (280 and $217 \mathrm{bp}$ ) represent males ( $\mathrm{X}$ and $\mathrm{Y}$ amplification) and lanes with one band (280 bp) represent females ( $X$ amplification only).

\section{DISCUSSION}

In this study, we initially analyzed the viability of the alkaline lysis DNA extraction method in cells, along with its performance in the amplification of two PCR product sizes: an SA (150 bp), and an LA (550 bp) size. Our results clearly demonstrated that the protocol is highly efficient $(99.6 \%$ of amplification) when used for small PCR products. The lower rate of positive PCR samples in the LA group $(80.1 \%)$ can be explained by the generation of chain scissions resulting from depurination followed by hydrolysis of the sugar-phosphate backbone of the DNA molecule when incubated with $\mathrm{NaOH}$ (Ullman and Mccarthy, 1973). For this reason, the smaller the amplicon size, the better the PCR efficiency.

A practical use of the $\mathrm{NaOH}$-based DNA extraction method is molecular embryo sexing, because it employs a sole pair of amelogenin primers (Ennis and Gallagher, 1994) that results in small amplicons (280 and 217 bp for $X$ and Y, respectively). The mean cost of PCR and electrophoresis using our procedure was close to US\$ 2 per sample, which represents a cost reduction of $50-130 \%$ using the $\mathrm{NaOH}$ extraction method when compared with established DNA extraction kits from renowned suppliers. Using the $\mathrm{NaOH}$-based DNA extraction method (detailed in Figure 2A), an efficient mean sex determination rate for embryos was achieved (95.9\%) from a significant number of samples (1847 embryos and embryo biopsies), which is in accordance with other studies on livestock embryo sexing (Macháty et al., 1993; Tominaga and Hamada, 2004) (see Table 2).

One of the main advantages of the proposed embryo sexing procedure is the DNA extraction protocol. The first described HotShot alkaline lysis (Truett et al., 2000) was employed to extract genomic DNA from mouse tissues, taking up to $1 \mathrm{~h}$ to extract the DNA for PCR analysis. By changing the concentrations of the $\mathrm{NaOH}$ and Tris solutions, and adjusting the incubation times, we successfully extracted PCR-quality DNA in less than $20 \mathrm{~min}$ on a high throughput scale. In addition to embryo sexing and goat $h L Z$ transgenic fibroblast amplicon amplification, as described in this study, we also extracted genomic DNA from other goat fibroblast cells, and from cattle, dog, and human cultured cells, and performed PCR and multiplex PCR to successfully amplify endogenous and/or transfected transgenes ranging from 100 to $700 \mathrm{bp}$ (Tavares KCS, Carneiro IS, Rios DB, Feltrin C, et al., unpublished data).

An additional potential application for the $\mathrm{NaOH}$-based DNA extraction protocol is for preimplantation genetic diagnosis (PGD), which emerged about 20 years ago in humans with the advent of embryo biopsies (Handyside et al., 1989), allowing researchers to analyze the genome and screen for potential genetic diseases and markers for production-related traits prior to embryo transfer (Verlinsky et al., 1990). In livestock, the main reason for applying PGD is sex determination, but other applications are emerging in this vastly unexplored field, such as for the screening of microsatellites (Hirayama et al., 2004), polymorphic alleles linked with commercial features, e.g., growth hormone, $\kappa$-casein, and prolactin (Chrenek et al., 2001), and scrapie resistance (Dervishi et al., 2011), among others. 
Alkaline lysis, as described in this study, provides a simple and inexpensive means of analyzing the genome of a cell or embryo. The technique does not require enzymes, such as proteinase $\mathrm{K}$, restriction endonucleases for restriction fragment length polymorphism (Almodin et al., 2005), whole genome amplification, nested PCR to increase the sensibility of PCR (Chrenek et al., 2001), or commercial kits (Dervishi et al., 2011). As the present protocol uses only $2 \mu L$ DNA for each PCR run, up to ten different amplification analyses can be performed for each embryo biopsy. The biopsy procedure using a blade to excise a portion of the embryo did not affect the in vitro embryo development potential, which is corroborated by other studies in which pregnancy rates for blade-biopsied embryos were comparable to non-biopsied structures (Lopatarova et al., 2008).

\section{CONCLUSIONS}

The combination of the modified HotShot alkaline lysis DNA extraction procedure and amelogenin-directed primers allowed the rapid and low-cost sexing of 1847 bovine and ovine embryos and embryo biopsies in approximately $2 \mathrm{~h}$. In addition to sex determination prior to embryo transfer, this procedure could potentially be used for the PGD of other gene sequences or alleles. It could become a useful tool for producers who wish to select and transfer only embryos of the desired sex or produce disease-resistant traits.

\section{Conflicts of interest}

The authors declare no conflict of interest.

\section{ACKNOWLEDGMENTS}

We thank Dr. Elizabeth A. Maga and Dr. James D. Murray from the University of California at Davis for providing the goat fibroblast cells transgenic to the human lysozyme gene that were used to validate the extraction method in Experiment 1 of this study. Research supported by FINEP/ MCT/Brazil.

\section{REFERENCES}

Almodin CG, Moron AF, Kulay L Jr, Minguetti-Câmara VC, et al. (2005). A bovine protocol for training professionals in preimplantation genetic diagnosis using polymerase chain reaction. Fertil. Steril. 84: 895-899.http://dx.doi.org/10.1016/j. fertnstert.2005.02.051

Blondin P, Beaulieu M, Fournier V, Morin N, et al. (2009). Analysis of bovine sexed sperm for IVF from sorting to the embryo. Theriogenology 71: 30-38.http://dx.doi.org/10.1016/j.theriogenology.2008.09.017

Carneiro MC, Takeuchi PL, Araújo A, Lôbo RB, et al. (2011). Sexing single bovine blastomeres using TSPY gene amplification. Genet. Mol. Res. 10: 3937-3941.http://dx.doi.org/10.4238/2011.October.25.1

Chrenek P, Boulanger L, Heyman Y, Uhrin P, et al. (2001). Sexing and multiple genotype analysis from a single cell of bovine embryo. Theriogenology 55: 1071-1081.http://dx.doi.org/10.1016/S0093-691X(01)00467-8

Davis ME and Haibel GK (1993). Use of real-time ultrasound to identify multiple fetuses in beef cattle. Theriogenology 40: 373382.http://dx.doi.org/10.1016/0093-691X(93)90275-A

Davoudi A, Seighalani R, Aleyasin SA, Tarang A, et al. (2012). A low-cost efficient multiplex PCR for prenatal sex determination in bovine fetus using free fetal DNA in maternal plasma. Int. J. Fertil. Steril. 6: 45-50.

De Vries A, Overton M, Fetrow J, Leslie K, et al. (2008). Exploring the impact of sexed semen on the structure of the dairy industry. J. Dairy Sci. 91: 847-856.http://dx.doi.org/10.3168/jds.2007-0536

Dervishi E, Sánchez P, Alabart JL, Cocero MJ, et al. (2011). A suitable duplex PCR for ovine embryo sex and genotype of 
PrnP gene determination for MOET-based selection programmes. Reprod. Domest. Anim. 46: 999-1003.http://dx.doi. org/10.1111/j.1439-0531.2011.01774.x

Ennis S and Gallagher TF (1994). A PCR-based sex-determination assay in cattle based on the bovine amelogenin locus. Anim. Genet. 25: 425-427.http://dx.doi.org/10.1111/j.1365-2052.1994.tb00533.x

Feltrin C, Cooper CA, Mohamad-Fauzi N, Rodrigues VH, et al. (2014). Systemic immunosuppression by methylprednisolone and pregnancy rates in goats undergoing the transfer of cloned embryos. Reprod. Domest. Anim. 49: 648-656.http:// dx.doi.org/10.1111/rda.12342

Garner DL, Gledhill BL, Pinkel D, Lake S, et al. (1983). Quantification of the X- and Y-chromosome-bearing spermatozoa of domestic animals by flow cytometry. Biol. Reprod. 28: 312-321.http://dx.doi.org/10.1095/biolreprod28.2.312

Ginther OJ (1998). Ultrasonic imaging and animal reproduction: book 3, cattle. Equiservices Publishing, Cross Plains, Wisconsin.

Grant VJ and Chamley LW (2007). Sex-sorted sperm and fertility: an alternative view. Biol. Reprod. 76: 184-188.http://dx.doi. org/10.1095/biolreprod.106.056259

Handyside AH, Pattinson JK, Penketh RJ, Delhanty JD, et al. (1989). Biopsy of human preimplantation embryos and sexing by DNA amplification. Lancet 1: 347-349.http://dx.doi.org/10.1016/S0140-6736(89)91723-6

Hirayama H, Kageyama S, Moriyasu S, Hirano T, et al. (2004). Genetic diagnosis of claudin-16 deficiency and sex determination in bovine preimplantation embryos. J. Reprod. Dev. 50: 613-618.http://dx.doi.org/10.1262/jird.50.613

Hughes EA and Davies DA (1989). Practical uses of ultrasound in early pregnancy in cattle. Vet. Rec. 124: 456-458.http:// dx.doi.org/10.1136/vr.124.17.456

Johnson LA, Flook JP and Look MV (1987). Flow cytometry of X and $Y$ chromosome-bearing sperm for DNA using an improved preparation method and staining with Hoechst 33342. Gamete Res. 17: 203-212.http://dx.doi.org/10.1002/ mrd.1120170303

Kadivar A, Hassanpour H, Mirshokraei P, Azari M, et al. (2013). Detection and quantification of cell-free fetal DNA in ovine maternal plasma; use it to predict fetal sex. Theriogenology 79: 995-1000.http://dx.doi.org/10.1016/j.theriogenology.2013.01.027

Kageyama S, Yoshida I, Kawakura K and Chikuni K (2004). A novel repeated sequence located on the bovine Y chromosome: its application to rapid and precise embryo sexing by PCR. J. Vet. Med. Sci. 66: 509-514.http://dx.doi.org/10.1292/ jivms.66.509

Lopatarova M, Cech S, Krontorad P, Holy L, et al. (2008). Sex determination in bisected bovine embryos and conception rate after the transfer of female demi-embryos. Vet. Med. Czech 53: 595-603.

Lopatarova M, Cech S, Krontorad P, Holy L, et al. (2010). Conception rate after sex determination and cryopreservation of D7 bovine embryos. Vet. Med. Czech 55: 10-18.

Lopes RF, Forell F, Oliveira AT and Rodrigues JL (2001). Splitting and biopsy for bovine embryo sexing under field conditions. Theriogenology 56: 1383-1392.http://dx.doi.org/10.1016/S0093-691X(01)00641-0

Lu KH and Seidel GE, Jr. (2004). Effects of heparin and sperm concentration on cleavage and blastocyst development rates of bovine oocytes inseminated with flow cytometrically-sorted sperm. Theriogenology 62: 819-830.http://dx.doi. org/10.1016/j.theriogenology.2003.12.029

Macháty Z, Páldi A, Csáki T, Varga Z, et al. (1993). Biopsy and sex determination by PCR of IVF bovine embryos. J. Reprod. Fertil. 98: 467-470.http://dx.doi.org/10.1530/jif.0.0980467

Mara L, Pilichi S, Sanna A, Accardo C, et al. (2004). Sexing of in vitro produced ovine embryos by duplex PCR. Mol. Reprod. Dev. 69: 35-42.http://dx.doi.org/10.1002/mrd.20147

Park JH, Lee JH, Choi KM, Joung SY, et al. (2001). Rapid sexing of preimplantation bovine embryo using consecutive and multiplex polymerase chain reaction (PCR) with biopsied single blastomere. Theriogenology 55: 1843-1853.http://dx.doi. org/10.1016/S0093-691X(01)00526-X

Peippo J, Vartia K, Kananen-Anttila K, Räty M, et al. (2009). Embryo production from superovulated Holstein-Friesian dairy heifers and cows after insemination with frozen-thawed sex-sorted X spermatozoa or unsorted semen. Anim. Reprod. Sci. 111: 80-92.http://dx.doi.org/10.1016/j.anireprosci.2008.02.002

Rattanasuk S, Parnpai R and Ketudat-Cairns M (2011). Multiplex polymerase chain reaction used for bovine embryo sex determination. J. Reprod. Dev. 57: 539-542.http://dx.doi.org/10.1262/ird.10-126M

Ribeiro ES, Gerger RP, Ohlweiler LU, Ortigari I, Jr., et al. (2009). Developmental potential of bovine hand-made clone embryos reconstructed by aggregation or fusion with distinct cytoplasmic volumes. Cloning Stem Cells 11: 377-386.http://dx.doi. org/10.1089/clo.2009.0022

Seidel GE, Jr., Schenk JL, Herickhoff LA, Doyle SP, et al. (1999). Insemination of heifers with sexed sperm. Theriogenology 52: 1407-1420.http://dx.doi.org/10.1016/S0093-691X(99)00226-5

Shea BF (1999). Determining the sex of bovine embryos using polymerase chain reaction results: a six-year retrospective study. Theriogenology 51: 841-854.http://dx.doi.org/10.1016/S0093-691X(99)00030-8 
Tominaga K (2004). Cryopreservation and sexing of in vivo- and in vitro-produced bovine embryos for their practical use. J. Reprod. Dev. 50: 29-38.http://dx.doi.org/10.1262/jrd.50.29

Tominaga K and Hamada Y (2004). Efficient production of sex-identified and cryosurvived bovine in-vitro produced blastocysts. Theriogenology 61: 1181-1191.http://dx.doi.org/10.1016/j.theriogenology.2003.07.008

Truett GE, Heeger P, Mynatt RL, Truett AA, et al. (2000). Preparation of PCR-quality mouse genomic DNA with hot sodium hydroxide and tris (HotSHOT). Biotechniques 29: 52-54, 54.

Tsai TC, Wu SH, Chen HL, Tung YT, et al. (2011). Identification of sex-specific polymorphic sequences in the goat amelogenin gene for embryo sexing. J. Anim. Sci. 89: 2407-2414.http://dx.doi.org/10.2527/jas.2010-3698

Ullman JS and McCarthy BJ (1973). Alkali deamination of cytosine residues in DNA. Biochim. Biophys. Acta 294: $396-404$. http://dx.doi.org/10.1016/0005-2787(73)90094-4

Verlinsky Y, Pergament E and Strom C (1990). The preimplantation genetic diagnosis of genetic diseases. J. In Vitro Fertil. Embryo Transfer 7: 1-5.

Wang G, Cui Q, Cheng K, Zhang X, et al. (2010). Prediction of fetal sex by amplification of fetal DNA present in cow plasma. J. Reprod. Dev. 56: 639-642.

Zhang M, Lu KH and Seidel GE (2003). Development of bovine embryos after in vitro fertilization of oocytes with flow cytometrically sorted, stained and unsorted sperm from different bulls. Theriogenology 60: 1657-1663.http://dx.doi. org/10.1016/S0093-691X(03)00177-8

Zoheir KM and Allam AA (2010). A rapid method for sexing the bovine embryo. Anim. Reprod. Sci. 119: 92-96.http://dx.doi. org/10.1016/j.anireprosci.2009.12.013 